\title{
GOLD POWDER: \\ Its PREPARATION \& APPLICATION \\ as Described in Ancient Sanskrit Texts
}

\author{
R.K. Dube \\ Department of Metallurgical Engineering, \\ Indian Institute of Technology, \\ Kanpur 208016, India
}

In this article

the origin and development of the technology of gold powder in ancient India is described on the basis of the literary evidence cited in various Sanskrit texts. The applications of gold powder as described in these texts are also discussed.

Basically two techniques -

mechanical comminution and chemical methods were used in Indian antiquity for making gold powder.

However, there were many variants of these techniques, which are described in detail below.

It has been shown that two important applications

of gold powder in ancient India were in medicine and for making colours for painting. 
G old has attracted mankind since time immemorial. Its pleasant colour, resistance to corrosion, and ease of forming and joining have made it a valuable metal widely used for making jewellery. There are numerous references to gold and gold jewellery in the ancient Sanskrit texts of India, such as Vedas, Vālmikiya's Rāmāyana, Mahābhārata, etc. In ancient India, gold was also used in powder form, and written evidence is available in the ancient Sanskrit texts indicating how it was produced and for what purposes it was used. These texts are not directly related to metallurgy, but concern sculpture, painting, medicine, etc., and indirectly give information on the science and technology of metals.

The present article describes the techniques used for the manufacture of gold powder and its application in various fields, as depicted in ancient Sanskrit texts. The texts referred to for this purpose are: Mahābhārata, Viṣnudharmottara, Purāṇa, Mānsollāsa, Śilparatna, CarakaSaṃhitā, Suśruta Saṃhitā, Rasaratnasamuccaya, Rasendracudamani and Rasaprakāśsasudhākara. All of these texts are written in Sanskrit.

\section{A BRIEF}

\section{DESCRIPTION}

\section{OF THE TEXTS}

Mahābhärata [1] is one of the most important epics of India, and was composed in the fifth or sixth century B.C. [2]. Caraka Samhitā [3] and Suśruta Samhitā [4] are amongst the oldest Sanskrit texts on Indian medicine and surgery. Upadhyaya [5] and Sharma [6]. have discussed the date of composition of these works in detail. Âtreya Punarvasu taught the contents of Caraka Samhita in the sermons to his disciples. His disciple Agnivesha composed the book in the fifth century B.C. Later on Caraka enlarged the condensed portion and abridged the expanded portion of the text in the second century B.C. Subsequently, Dradhabala added seventeen chapters at the end of the Cikitsāthanna section, making a total of thirty chapters in all. He also added two new sections, namely Kalpasthāna and Sidhisthāna. The date of Dradhabala is believed to be in the fourth century A.D. Ray [7] places the original work of Caraka in the pre-Buddhist era. Suśruta Sampitã is a revised version of an earlier work. The revision was carried out by Suśruta in the second century B.C. Some authors are of the opinion that the work was again revised by enlarging the condensed portion and shortening the enlarged portion by Nāgārjuna in the fifth century A.D. Some corrections were made to the text by Candrata, in the tenth century A.D.

Viṣnudharmottara Purana [8] is an encyclopaedic work comprising stories, myths and legends, together with cosmology, geography, astronomy and astrology, law and politics, techniques of war, anatomy, medicine, manufacture of perfumes, techniques of dance, vocal and instrumental music, sculpture, painting, architecture, etc. Hazara [9] has indicated that this work cannot be dated earlier than A.D. 400 nor later than A.D. 500. Bühler [10] also believes that this work cannot have been written later than A.D. 500 .

Mānasoltasa [11], which deals with various topics relating to the needs of royal families, was composed by Bhulokamalla in A.D. 1131. The subject matter of this work includes various types of entertainment, royal sports, music, astrology, materials for painting, iconometry, various types of pictures, systems of teaching of princes, science of precioụs stones, etc. Silpâaratna [12] is a Sanskrit text on sculpture written by Srikumara. He appears to have compiled the text from earlier Silpa and Agama works, with some modifications. The date of the composition of this text has been assigned to the latter part of the sixteenth century, A.D.

An independent medicinal science, known as RasaSāstra, which dealt with the use of mercury for making fine powder of various metals and alloys for medicinal preparations, came into existence in ancient India. Rasaratnasamuccaya [13], written by Vāgbhata, is an important work on this subject. There are two opinions 
about the date of composition of this text. According to the first opinion [14] the text was written in the ninth century A.D., while the second [15] holds it to be composed in the thirteenth century A.D. The former date seems to be more probable. Rasendracudāmani [16] and Rasaprakasasudhakara [17] are texts on the same subject composed in the twelfth century A.D.

\section{Naturally Occurring}

\section{GOLD POWDER}

There is a reference to naturally occurring gold powder in Mahābhàrata. The most interesting feature of these powders is that they were collected from the natural environment by ants and were known as "Pipilika" gold (Pipilika is the Sanskrit word for ants). This type of gold powder was presented to King Yudhisthira at the time of the Rajasuya Yagna ceremony by various kings

(Figure 1). The relevant Sanskrit text from Mahābhārata

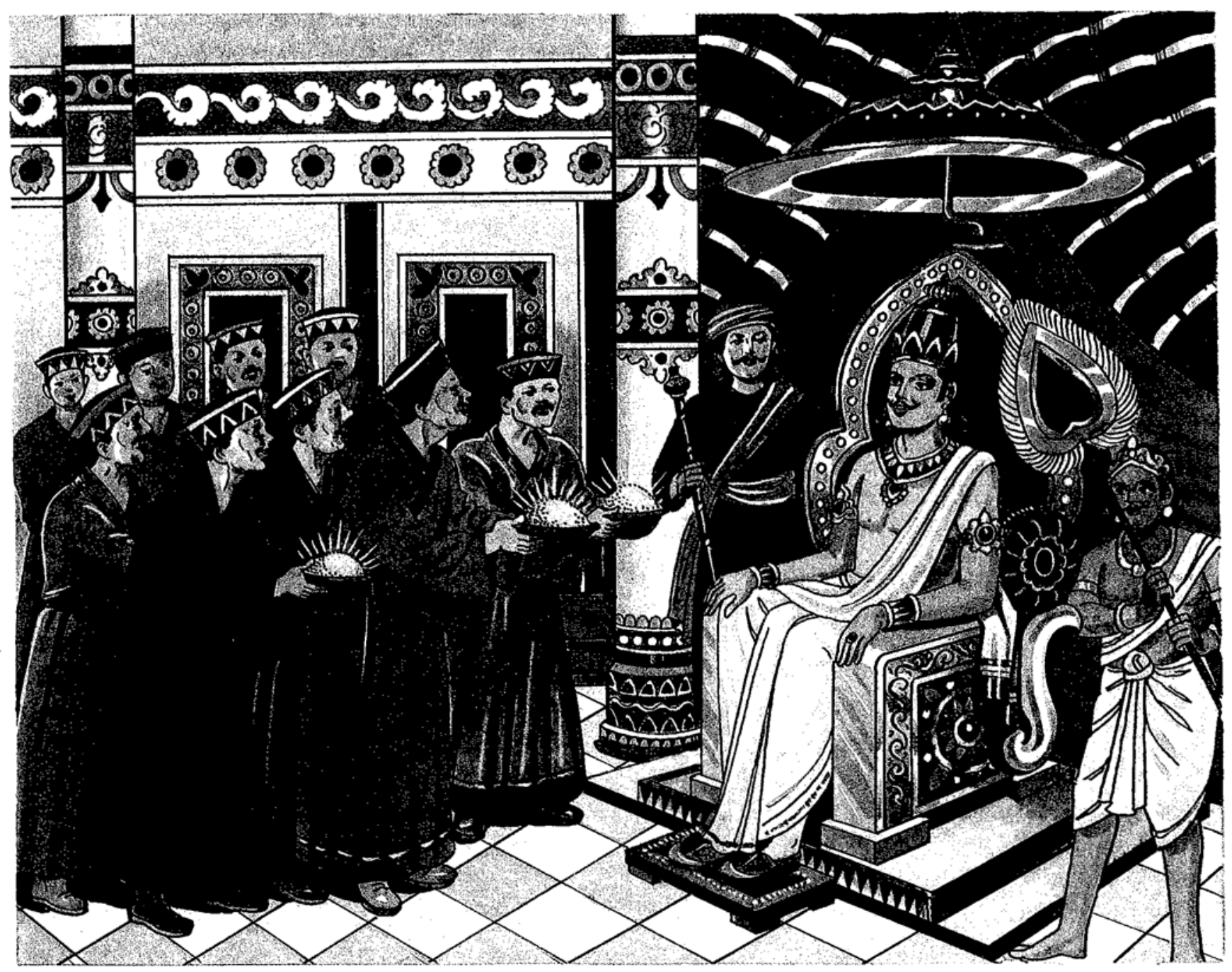

Figure 1:

King Yudhisthira being presented with "Pipilika" gold powder by the kings from the Khasa, Ekāsana, Arha, Pradara, Dirghavenu, Pārada, Pulinda, Tangana and Paratangana peoples at the time of the Rajjasuya Yagna Ceremony 
सौवर्ण सुकृतं चूर्ण कुष्ठ मधु घृतं वचा । मत्स्याक्षकः रा पुण्पी मधु सर्षिः सकाश्वनम् ॥७२॥ अर्कपुष्पी मधु घृतं चूर्णित कनकं वचा। हेमचूर्णानि कैडर्यः श्वेता दूर्वा घृतं मधु ॥७३॥ चत्वारोडभिहिताः प्राशाः म्लोकार्धेषु चतुर्ष्वां। कुमाराणां घपुर्मेघाबलबुद्धिविवर्घनाः ॥७४:।

इति सुश्रुतसंहितायां शारीरस्थाने गर्भिणीव्याकरण शारीर नाम दशामोडयायः ॥?०॥

(बलुुद्धिवर्धक योग-) अच्छी तरह से तैयार किया हुआ सोने का चूर्ण, कुष्ठ, मधु, घी और वचा । मस्साक्षक

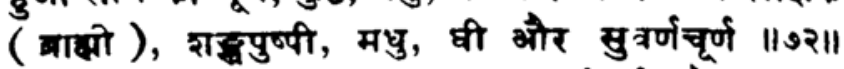
अर्कपुष्पी (पयस्या), मधु, ही, सुवर्णचूर्ण और वचा। सुवर्णचूर्ण, कैडर्य (कटफल, पर्वतनिम्ब) चत्तदूर्वा, घी और मधु "ज३॥ चार क्षोकार्षों में बताये हुए ये चार प्राश (लेह ) बालकों के शरीर, मेषा (प्रशणशाकि), शक्ति, वुद्धि को बढ़ाने वाले हैं (इनमें से किसी एक योग को प्रयुक्क करे ॥७४॥

Figure 2:

Sanskrit text from the Māhabhärata referring to "Pipilika" gold powder

(Sabhā, 52.2-4) is shown in Figure 2; the meaning of which is as follows:

"The kings of the Khasa, Ekāsana, Arha, Pradara, Dīrghaveṇu, Pārada, Pulinda, Tangaṇa and Paratangana peoples, who reside beneath the pleasing shadow of bamboo trees making a sound like that of Venu, due to air filled up in the pores of bamboo, situated on the banks of the Sailodā river flowing between the Meru and Mandarāchala mountains (in the Himālayan region), presented "Pipilaka" gold collected by ants, to King Yudhisthira. The unit of measurement (weight) of such gold powder was Droṇa."

Obviously these gold powder particles must have been fine in size, and might have been present in the sands of the Śailodà river. It seems there was a variety of ant which possessed expertise in collecting gold powder present in Nature. Megasthenes has also referred to such a type of ant existing in India.

\section{TECHNIQUeS USED}

FOR THE MANUFACTURE

\section{OF GOLD POWDER}

Caraka Samhitāa and Suśruta Samhitā have referred to gold powder for medicinal applications (dealt with in a later section) but no account of the method used for its manufacture is mentioned. It is believed that gold was rubbed onto a stone surface along with water, and the paste thus obtained was used for medicinal purposes. Such a practice is reported in the Sanskrit text Vrahadrasaräjasundara [18] written in 1894 A.D. The Viṣnudharmottara Purana (III.40.25-28) mentions the use of gold for making colour for painting. It is stated that gold must be thinned into leaves. Although the details for this process are not given - most probably because of secrecy - it seems likely that these leaves were ground mechanically to make powders. The texts from a later period clearly mention the details of the techniques used for making gold powder and these are described below.

\section{MECHANICAL}

\section{Comminution Method}

Mānasollasa and Silparatna give the full details of the technique used for making gold powder by mechanical comminution. Mānsasollasa (Vol. 2, 1.3.171-174) mentions the following method for preparing gold powder:

viraṇaị̣ sükș̣matundāgrairmẹdugharṣaṇyogatah. śuddhami suvarṇamatyartham śilayam paripeșitam. kritvā kānsyamaye pātre gālayettanmuhurmuhụh. li (kṣi)ptvām toyam tadalodya nihite(tam) tajjalam muhuh. yāvachhiłarajo yāti tavatkurvī yatnathah. ghanatvanmașrnam hem na yăti sah vāriṇa. āsteatinirmalam hem bałarkaruchirachhavi. tatkalkam hemajam svalpam vajralepena melayeta. 
The meaning of the above is as follows. Small pieces of pure gold, which are costly in price, should be slowly ground on a stone slab with a pointed tip tool known as a "tunda" together with virana grass (virana is a name of the fragrant grass "Andropogon Muricatus"). The mixture, thus produced, containing gold powder, is put into a bronze vessel. Enough water is poured into the vessel and the mixture is stirred frequently. The smooth gold powder remains inside the vessel because of its higher density. In this manner pure gold powder, having a colour similar to the rising sun, is prepared. The gold paste is mixed with a binder for further use as a colour for painting.

Silparatna (46.124-128) mentioned another method for making fine gold powder from gold leaves, as follows:

atha svarṇam peṣnartham patrikṛtya yathā mṛdu. tatpatram śaklīkṛtya sūkṣmāt sūḳṣmataram punah. kinchitsiktāsammișram śuddhatoyavimiṣrtam. peșayeta peșṇiśvabhre suślakṣṇaḍ̣sadä sudhih. jāte supiște tatpiṣte kāchpātre jalaih sah. àlodyordhvagatam pańka sikatām ca punah punah. santaya jātam svarnasya pankamatyujjvalam budhah.

The meaning of the above verses is as follows. Gold is turned into thin leaves, probably by hammering and is subsequently finely fragmented. These fine fragments of gold were mixed with small quantities of sand and water, and were ground in a mortar to convert the gold into powder form. The mixture was transferred into a vessel containing water, which was then thoroughly stirred. The water from the surface containing sand particles was panned. This process was repeated several times. In this way, gold powder free from sand particles was prepared and was used as a colour for painting after mixing with a suitable binder.

Muni Punyavijayaji [19] recorded the processes for making gold and silver powder, once practised in India. These were identical to that mentioned in Mānsollāsa and Silparatna. Two different processes have been described: one for the large-scale production and the other for small-scale production. Gold leaves are put into a hard stone mortar and levigated along with "dhau" gum solution. When the leaves have been turned into powder, sugared water is added and the entire mixture is thoroughly stirred in a pot. When the gold powder has settled down, the water is slowly drained away. The decanting process is repeated several times until no trace of "dhau" gum remains. After drying, the powder is ready for use. A different process has been described for producing gold powder in a small quantity. The "dhau" gum is smeared onto the surface of a glass dish and a gold leaf is placed on it. The leaf is turned into powder by a quick motion of the fingers over the surface of the dish. Thus the dish acted as a mortar and the finger as a pestle, the subsequent procedure being similar to that described above.

\section{Chemical Methods}

Chemical methods have been used to produce very fine gold powder, i.e. dust. Frequently during its preparation, small amounts of other ingredients are also added. Such very fine gold powder is known as gold "bhasma", and has been widely used to treat various ailments in Indian medicine. Mishra [20] has given a typical chemical analysis of gold bhasma as shown in Table I. It may be mentioned here that bhasma of various other metals are also used, and, in most cases, the bhasma is a very fine powder of some compound of these metals, together with some other ingredients.

\section{Table I:}

Chemical Analysis of a Typical Gold Bhasma

\begin{tabular}{|lc|}
\hline Constituent & Weight \% \\
$\mathrm{Au}$ & 96.76 \\
$\mathrm{SiO}_{2}$ & 1.14 \\
$\mathrm{Fe}_{2} \mathrm{O}_{3}$ & 0.14 \\
$\mathrm{CaO}$ & 0.55 \\
$\mathrm{P}_{2} \mathrm{O}_{5}$ & 0.78 \\
$\mathrm{~K}_{2} \mathrm{O}$ & 0.16 \\
$\mathrm{NaCl}$ & 0.08 \\
Sulphur Compound & 0.15 \\
Moisture & 0.25 \\
& \\
\hline
\end{tabular}


Rasaratnasamuccaya (5.15) has described a technique for making gold bhasma:

ḳ̣tvā kantakvedhyāni svarṇapatrāni lepayeta. lungämbubhasmas̄utena mryate dașabhih putah.

This text describes how thin leaves of gold, which can be pierced by a thorn, are smeared with a paste prepared from mercury bhasma (probably an oxide of mercury) and lemon juice, and are heated in a crucible. Fine gold bhasma is obtained after subjecting the leaves to heating ten times. Rasendracudāmaṇi has also referred to this technique. Rasaratnasamuccaya has described two other variants of the same process, which, in principle, are similar to the above.

Adifferent process has been described in Rasendracudāmaṇi (14.19-20) for making gold bhasma:

sūten piṣtikam ḳ̣tvā svarṇam rudhvā śarāvake. svalpanitanjanopetam dagdham svlpairvatotpalaih. kumkumābham bhavedbhyasya yojyam rasarasāyne.

Pieces of gold foil are mixed with mercury and the mixture is left for two days. Then a very small amount of Neelānjana ( $\mathrm{PbS}$ ) is added to it. The mixture is put into a crucible and fired. The process is repeated several times. In the end saffron coloured fine gold bhasma is obtained.

Rasaratnasamuccaya (8.26-27) classifies various types of bhasmas. Those bhasmas which float on the water are called "vāritar bhasma". Those bhasmas which get entrapped in the fine grooves of the palm after rubbing with the fingers and do not get dislodged even after dusting, are called "rekhāpurṇa bhasma". The latter type is much finer than the former.

\section{Applications of Gold POWder}

One of the earliest applications of gold powder in ancient India, as mentioned in the "Visnudharmottara
Purana" (III.40.25-28) was in the manufacture of colours for painting. This particular application of gold powder continued with time, as suggested by the references cited in Mānasollāsa and Śilparatna. The powder was mixed with a binder solution to prepare it for painting. After painting, the colours were allowed to dry and then rubbed with a boar-tusk repeatedly until the lustre of gold was obtained.

Fine gold powder, typically known as gold bhasma, was widely used for medicinal purposes in ancient India. This, in combination with other ingredients, was also used in making new medicinal preparations. It is mentioned in Caraka Samphitā (Ch. 23.239-240) that poison has no effect on people who take gold powder regularly:

suddhe hṛdi tatah śāṇam hemacurṇsya dāpayeta. hema sarvavișānyāśu garāñśsca viniyachhati. na sajjata hemapange visam padmadalembuvat.

Śusruta (Śarira, 10.72-74) formulated four compositions of tonics for children, each of which contained gold powder as an important ingredient.

sauvarnam sukṛtam curṇam kuṣtham madhu ghṛtam vacā. matsyākskah sámkhapuṣpi madhu sarpih sakāncanam. arcapuspi madhu ghṛtam curnitam kanakam vacā. hemacurnani kaidaryah śveta dūrvā ghrtam madhu. catvarobhihitah prāsāâh ślakardhesu catursvapi. kumāraṇām vapurmedhậalabuddhivivardhanā.

For example, one tonic was made up of gold powder, kushtha, honey, clarified butter and vaca. Each of these tonics was used for improving the physical strength and the "brain power" of children.

Sanskrit texts on Indian medicine have described a large number of medicinal preparations, in which gold bhasma is an important ingredient. For example, Rasaratnasamuccaya (14.14-17, 15.50-61, 17.90-99) and 17.124-128) describes many such preparations, 
e.g. Rãjamrgankarasa, Kanakasundarirasa, and Basantakusumakararasa, which were used for treating a wide variety of ailments, such as tuberculosis, severe body pain, indigestion, weakness, jaundice, high fever, respiratory troubles, etc. Rasendracudāmaṇi (14.15), states that people who take gold bhasma regularly for ten years remain healthy for the rest of their lives and do not suffer from any disease.

daśābdasevitam svarṇam svechhāharaviharinam. na kaścidvādhate vyadhiryāvadāyurn samísayah.

Rasaprakásasudhakara (4.20) indicates that the beginning of the aging process in human beings is delayed if they take gold bhasma along with honey:

etatsvrnabhavam karoti ca rajah saundaryasaukhye sadā. rogān daivakrtannihanti sakalan satyam trdoṣodbhavān. yạ seveta narah saman dvidaśakan vṛ̣̣̣̣̣sca no jäyate. doṣā naiva garodbhavā viṣkṛtā āgantujāścaiva hi.

\section{Summary \& Concluding Remarks}

It is possible to deduce the chronological development of the technology of gold powder in ancient India on the basis of the literary evidence reported in this article. It must be emphasised that the reference to any product or process in the earliest possible text illustrates the fact that this particular product or process was certainly in use by the time the text was composed. Evidently, however, this product or process might have been in use even earlier than the date of the text. Therefore, the chronological development of a product or process deduced from literary evidence must be viewed in the light of the above.

From this account of the evidence derived from ancient Sanskrit texts, it is apparent that gold powder in India has a long history. The first literary reference to gold powder dates back to as early as the fifth or sixth century B.C. This was a naturally occurring powder collected by ants. This form of gold was considered to be a novelty. The references available in "Suśruta Samhita" suggest that by the second century B.C., or even earlier, gold powder was in use for medicinal applications in India. Most probably the method used for making such gold powder consisted of rubbing gold pieces on a hard stone, together with water. An important turning point in the history of gold powder in India occurred in about the fourth century A.D. when it was produced from thin gold leaves for use in making colours for painting. Another important landmark in the production of gold powder dates from about the ninth century A.D. and was associated with the development of a new branch of Indian medicine known as "Rasa Sāstra" in which fine gold powder, typically known as gold bhasma, was produced by the amalgamation technique. The Sanskrit texts on Rasa Sãstra of this period, and also of the subsequent period, are full of the details of the various variants of this technique for making gold bhasma, which was, and still is, used in medicinal applications.

All of the above techniques continued to develop further with time. The Sanskrit texts of the twelfth and sixteenth centuries A.D. have well-documented details of the different variants of the mechanical communition technique for making gold powder from thin gold leaves or small gold pieces, to be used as colorants for painting. An interesting aspect was that there were separate techniques for the large scale and small scale production of such gold powder.

Thus it can be seen that in ancient India gold powder flourished throughout the ages. The two important areas of its application were in medicine and making colours for painting. The methods used for each application were basically different, and sustained efforts were made to constantly develop and refine the techniques. The use of gold powder as a colorant in painting in other parts of the world in ancient times has been reported [21], but the application of fine gold powder in medicine developed in ancient India was unique in the contemporary world. 


\section{REFERENCES}

1 Mahābhāata, trans. R.D.N. Shastri Pandey, Gita Press, Gorakhpur, 1989.

2 Baldeva Upadhyaya, Sanskrit Sāhitya Kā Itihāsa, Sharda Niketan, Varanasi, 1985, 61.

3 Caraka Samhitā. Ed. Dr. Rajeswara Dutt Shastri, et al. Chaukhambha Bharati Academy, Varanasi, 1984.

4 Suśruta Samhitā, Ed. B.G. Ghadekar, Meharchand Lakshmandas, Delhi, 10th Ed., 1989.

5 Baldeva Upadhyaya, Sanskrit Sāstron Kā Itihāsa, Sharda Sansthan, Varanasi, 1969, 8-21.

6 P.V. Sharma, Āyurveda Kā Vaigyānika Itihāsa, Chaukhambha Orientalia, Varanasi, 1975, 57-113.

7 P. Chandra Ray, in "History of Chemistry in Ancient and Medieval India", Ed. P. Ray, Indian Chemical Society, Calcutta, 1956, 60.

8 Viṣnudharmottara Purạna, Ed. Madhusudan and Madhavaprasad Sharma, Venkatesvara Press, Bombay, 1913.

9 R.C. Hazara, in: Studies in the Upapurāna, 1, Sanskrit College, Calcutta, 1958, 212.

10 G. Bühler, Ind. Ant., 1890, 19 , 408.

11 Mānasollasa, Vols. 1 and 2, Ed. G.K. Shrigondekar, Oriental Institute, Baroda, 1967.
12 Silparatna, Ed. T. Ganapati Sastri. Trivandrum Sanskrit Series, no. 98, Trivandrum, 1921.

13 Rasaratnasamuccaya, Ed. D.A. Kulkarni, M. Lakshmandas, Delhi. 3rd Edition, 1982.

14 Baldeva Upadyaya, Sanskrit Śāstron Kā Itihāsa, Sharda Sanathan, Varanasi, 1969, 27.

15 P.V. Sharma, Âyurveda Kā Vaigyānika Itihāsa, in: Chaukhambha Orientalia, Varanasi, 1975, 460.

16 Rasendracudamani, in: Chaukhambha Orientalia. Ed. S. Mishra, Varanasi, 1983.

17 Rasaprakāsasudhākara. Ed. S. Mishra, Chaukhambha Orientalia, Varanasi, 1983.

18 D.R. Chaube. Vrahadrasaräjasundara, in: Gyansager Press, Kishangarh, 1894.

19 Jain-Citrakalpadruma, 1, in: Technique of Indian Painting, A.K. Bhattacharya, Calcutta, 1976, 80).

20 S. Mishra, Āyurvediya Rasásāstra, in: Chaukhambha Orientalia, Varanasi, 1990, 518.

21 W.D. Jones, in: Fundamental Principles of Powder Metallurgy, Ed. E. Arnold, London, 1960, 204. 